\title{
Hydrophobization of fine solids presented on the example of limestone powder
}

\author{
Elżbieta Vogt \\ University of Science and Technology, Faculty of Fuels and Energy, al. Mickiewicza 30, 30-059 Kraków, Poland, \\ e-mail:vogt@agh.edu.pl
}

\begin{abstract}
The work proposes a new method of hydrophobization of limestone powder from stearic acid vapour or stearic acid ether solution. The obtained product is characterised by all properties typical of water-resistant materials. The evaluation of these properties has been carried out according to Polish Standard PN-G-11020 and analysed with research methods originally used for powder technique.
\end{abstract}

Keywords: hydrophobization, limestone powder.

\section{INTRODUCTION}

Materials characterised by hydrophobic properties are used in both everyday life and in many industry domains. They are applied, in particular, in building industry ${ }^{1}$. In paper industry, for hydrophobization, the so-called sizing substances are applied. The limestone dust is used generally in mining industry, as a protective substance, against coal dust explosions. In Poland dust barriers consisting of a series of shelves with the limestone hydrophobic dust deposit are used for this purpose ${ }^{2}$ -3 . A typical method of hydrophobic dust production (milling limestone with stearic acid) is no longer profitable, or sometimes even impossible in modern quarries.

\section{HYDROPHOBIZATION METHODS}

In general terms, methods of hydrophobization can be divided into protection of material surface by substances characterised by the hydrophobic properties or the modification of the properties inside the material volume ${ }^{4}$. Irrespective of the hydrophobization technique used, the modifying agent should be selected in the manner that does not change the specified properties of the waterproof material, which are important for the usage. Moreover, the modifier should be colorless, incombustible, harmless for health and environment, resistant to weather conditions, and it also should easily form compounds with the hydrophobized material ${ }^{4-5}$ and not change over time.

\section{LAYER HYDROPHOBIZATION}

Decreasing of the wettability of solids characterised by large surfaces is achieved by coating final products with a hydrophobic layer ${ }^{6}$ by means of painting, spraying or by bath dipping, ${ }^{7}$. Silicone agents were given attention in many works on hydrophobization of building materials $\mathrm{s}^{\mathbf{1 , 4 - 5}, 7}$. Sodium ethyl silicone or ethyl dichlorine silicone were used in this research and the contact angles on the protected material surface about $105^{\circ}, 117^{\circ}$ were obtained.

Silicones were also tested in other works ${ }^{8}$. The use of methyl silicone allowed for obtaining hydrophobic properties but their stability was not sufficient. In the case of silicone-based substances available on the market the same effect was observed for bricks and limestone ${ }^{5}$. The reason why hydrophobization was not sufficiently durable has been ascribed rather to bad adhesion of the silicones compounds to the material rather than to wrong selection of the hydrophobizing agent.
Other hydrophobization substances used for the protection of gypsum materials are various sorts of resins ${ }^{\mathbf{9}}{ }^{\mathbf{1 1}}$. Polyester $^{12}$ and epoxide resins contain epoxide and hydroxide groups whose interaction with each other does not only influence the cohesion but also their adhesion to the foundation, which makes them very useful for the hydrophobization process. The application of such resins as: phenolic-formalin ${ }^{\mathbf{1 0}}$, phenolicfurfuryl ${ }^{9}$, polyvinyl alcohol, carbamide-formalin and carbamide-melamine-formalin ${ }^{11}$ considerably reduces the absorbability of the studied materials.

Many other substances such as bituminous materials, tar, paraffins, ceresine, asphalt emulsion, oil and soluble wax ${ }^{4}$, green soap solution ${ }^{9}$, water glass ${ }^{\mathbf{4}, 13}$ were used for layer hydrophobization of the gypsum grout with various degrees of success.

The hydrophobization process may also be used for the protection of wooden surfaces ${ }^{\mathbf{6}}$ (for example bituminous, epoxide or polyester resins coats and artificial resin pressure impregnation).

Asphalt solution in low-boiling solvents like petrol or benzene also gives a good effect in layer hydrophobization ${ }^{6}$.

A mechanism of the layer hydrophobization quite different than the one described above takes place in the case of silica aerogel filter ${ }^{\mathbf{1 4}}$. The change of the surface's character was acquired by the modification consisting in hydrophobic groups interchange with less polar alkoxy groups.

Externally hydrophobized material may be also obtained by adding the hydrophobizing agent during the manufacture process. This technique is used both during the production of concrete mixtures and during the above-mentioned limestone milling process. Raw limestone material after preliminary breaking up in crushers was directed into tumbling mill, where the stearic acid was simultaneously added ${ }^{\mathbf{1 5}}$.

\section{Internal hydrophobization}

Colloidal suspension of ammonia salts of fatty acids-stearates, oleates, silicone resins and their derivatives or bituminous emulsion can be employed as internal hydrophobization substances for mortars or concretes $\mathbf{4}, \mathbf{1 6}$.

There is a large assortment of concrete polymer composites $^{6}$ characterised by hydrophobic properties. They are the building materials group modified by polymer substances. Their technical qualities depend on the sort and content of the polymer, as well as the form and procedure of introducing the modifier. Hydrophobization was also used with gypsum products, modifying them in their whole volume ${ }^{11,17}$. 
The literature review proves that the selection of hydrophobization substance is very important. The process conditions have an influence on the product properties as well as the chemical yield. Hydrophobic layer properties will also depend on the kind of specific surface, because its texture and chemical character influence the modifier penetration inside the material. Most of the described hydrophobization methods were used to protect the large-form solids. The modernization of mills at the quarry, mentioned already, caused the necessity of working out a new technique of dust material hydrophobization.

\section{EXPERIMENTAL}

In the research, an attempt of hydrophobization of the limestone powder from Czatkowice ${ }^{18}$ quarry was made, in order to protect the material from the loss of volatility properties. The limestone dust can agglomerate under humid conditions in mines. These investigations were done with the stearic acid used so far because of the specific application of the final product as a substance protecting human life. The use of other modifiers would lead to the necessity of conducting additional time consuming and expensive researches of dust usability.

The raw material was evaluated towards its fluidization capability according to Geldart's classification ${ }^{19}$ and its other properties were also measured - Tab. 2.

Geldart's classification makes it possible to evaluate the fluidization capacity of some materials on the basis of their density, fluid density or grain dimension. The fine solids are divided into 4 groups, depending on their behaviour in fluidization systems.

The sieve analysis of the raw limestone has been made. The average value of particle diameter $(19 \mu \mathrm{m})$ was calculated on the base of the obtained results. The dust was classified into the $\mathrm{C}$ dust group - i.e. the non-fluidizing material. The research conducted in fluidization column confirms this information - the fluid passes through the bed (it forms channels). It is the reason why the limestone dust cannot be hydrophobized in the fluidized bed.

The etheral solution of stearin acid was used as another way of limestone hydrophobization technique. The contents of stearin in the obtained water-proof samples were analyzed ${ }^{3}$. Moreover, their hydrophobic character has been studied, by the determination of the water adsorption isotherms, using the liquid microburette apparatus ${ }^{20}$.

The raw dust contains $0.126 \%$ stearin acid, whilst the hydrophobized sample: $0.453 \%$. It is the acceptable level according to the Polish Standard ${ }^{3}$. However, obtaining of the greater water vapor adsorption for the raw dust than for the hydrophobized one, proves that the product has not achieved the water resistance.

In search for other methods of the raw dust hydrophobization some limestone properties were estimated (bulk density, packed bulk density, compressibility, and angles of spatula repose, fall, difference or dispersibility) with the use of Powder Characteristic Tester-Hosokawa Micromeritics ${ }^{21}$ (Table 2). These parameters have their equivalents in the Polish Standard ${ }^{22}$ and they allow for the calculation of Carr or Hausner coefficients used in the latest methods of characterisation of powder materials ${ }^{23}$.

The dispersibility value determines the dust volatility. The value obtained (about $20 \%$ ) suggests that this limestone is a loose, largely spreading materia ${ }^{24}$. Therefore the process could be conducted similarly as in the case of limestone grinding but there is some obstacle. Uniform coating of each particle dust with stearic acid would be very difficult and intensive mixing would also be required. In this way the limestone would becme additionally broken-up (too fine) and this would not be good for its application. If limestone dust is too volatile it will be removed from dust barrier by a natural draught of ventilation occurring in mines ${ }^{25}$. Moreover, too fine dust may have a larger agglomeration propensity ${ }^{15}$.

Taking into consideration the results obtained during introductory tests a new method of limestone powder hydrophobization was proposed. It consists in stearic acid vapour and dust countercurrent flow. The laboratory apparatus was designed and it is shown in Figure. 1.

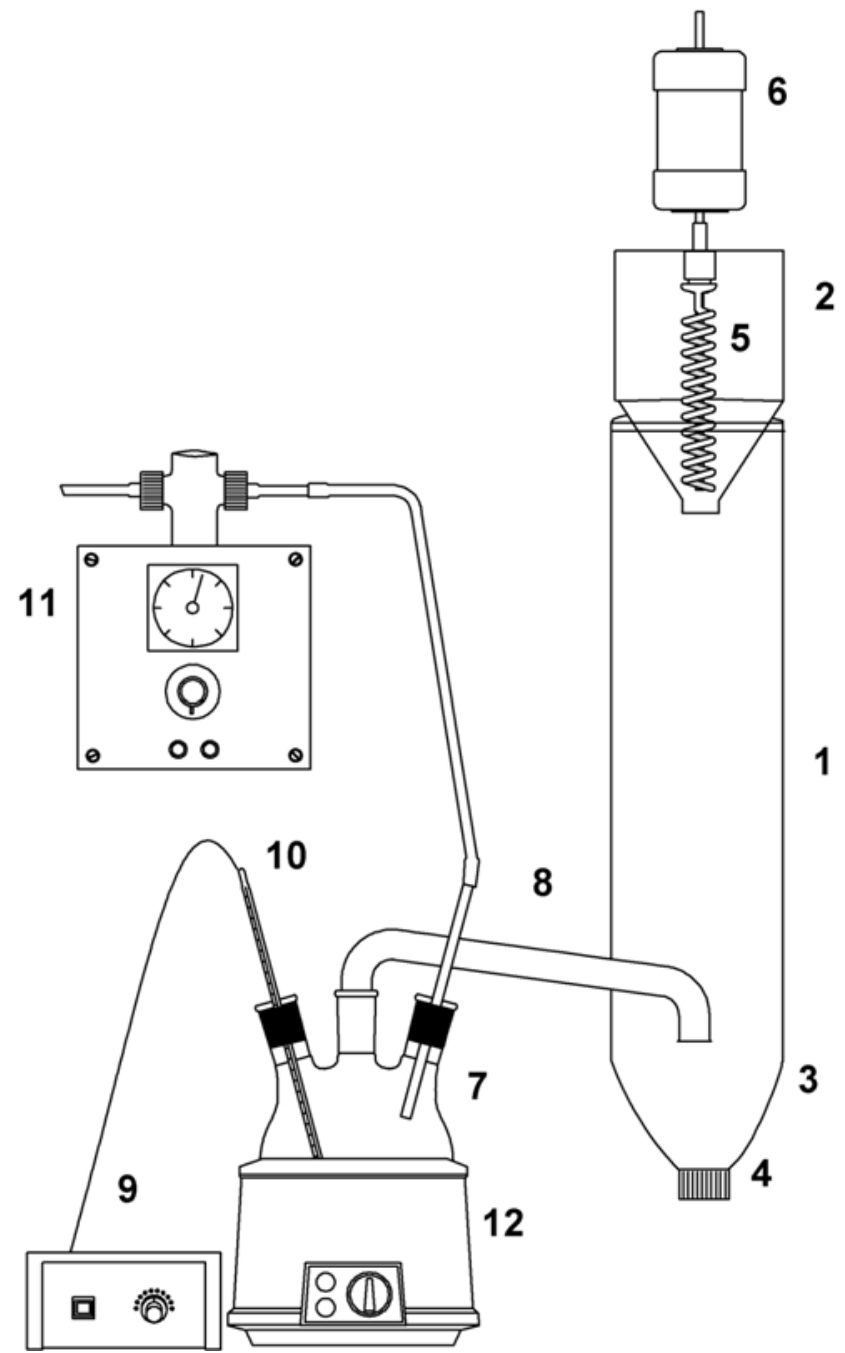

Figure 1. The hydrophobisation apparatus: 1 hydrophobisation column, 2, 3 - hoppers, 4 - lock of hopper, 5 - batcher, 6 - electric drive, 7 - boiler, 8 - ting up pipe, 9 - thermoregulator, 10 - thermocouple, 11 - compressor, 12 - heater

It was very difficult to obtain a uniform pulverization of limestone powder. A special construction batcher had to be used. The temperature $(443,453,473 \mathrm{~K})$ of heating up of the acid was established on the basis of Antoine's equation, so that the pressure of vapour was high enough (Table 1). The pump forced the continuous flow of stearic acid vapour.

The dust samples that were produced at the temperature $443 \mathrm{~K}$ were tested like raw limestone (the stearic acid contents, water absorbability). The obtained results indicate that the limestone product gained waterproof properties. The other characteristics of hydrophobized dust were obtained with the use of Powder Characteristic Tester ${ }^{21}$. The results were compared to the properties of the raw material (Table. 2). On the 
Table 1. The dependence of the stearic acid vapour pressure on temperature

\begin{tabular}{|l|c|c|c|c|c|c|c|l|}
\hline $\mathrm{T}[\mathrm{K}]$ & 293 & 323 & 373 & 423 & 443 & 453 & 463 & 473 \\
\hline $\mathrm{P}[\mathrm{Pa}]$ & $3.08 \cdot 10^{-4}$ & 0.01 & 1.26 & 36.04 & 107.88 & 179.02 & 289.74 & 458.2 \\
\hline
\end{tabular}

Table 2. The characteristic of raw and hydrophobized limestone dust

\begin{tabular}{|l|c|c|}
\hline & \multicolumn{2}{|c|}{$\begin{array}{c}\text { Limestone } \\
\text { Powder }\end{array}$} \\
\hline Dust characteristics & Raw & Hydrophobized (170/1) \\
\hline bulk density $\left[\mathrm{kg} / \mathrm{m}^{3}\right]$ & 724 & 815 \\
\hline packed bulk density $\left[\mathrm{kg} / \mathrm{m}^{3}\right.$ ] & 1475 & 1465 \\
\hline compressibility [\%] & 50.9 & 44 \\
\hline repose angle [deg] & 52 & 46.8 \\
\hline fall angle [deg] & 35 & 30.7 \\
\hline difference angle [deg] & 17 & 16 \\
\hline dispersibility [\%] & 20 & 39 \\
\hline
\end{tabular}

basis of the obtained characteristics the criterion of evaluation of hydrophobization degree was also searched.

The packed bulk density is about twice as large as bulk density and this gives the compressibility value that is equal about $50 \%$. Both the raw limestone dust and the hydrophobized powder will settle in elbows and the outlet will clog. When the limestone was feeding this behaviour of dust was observed.

The repose and fall angles for the hydrophobized and raw dust are a little different but the difference angles calculated on the basis of these are almost equal. The value of the difference angle for both the raw and the hydrophobized dust is rather low, like in the case of cohesive materials. It seems that as the criterion of the evaluation of the degree of hydrophobization of dust, the measurement of compressibility or dispersibility could be used. In the case of the second one the difference between the raw and the hydrophobized material is equal, about $20 \%$. However, these values for both samples are less than 50\% that is substandard for easy flowing powders.

\section{SUMMARY}

The results of the preliminary tests on limestone powder provoked an interest of the author in the subject area of hydrophobization of fine materials. Most of the works conducted in this domain are of utilitarian character or deal with an interaction between the modifier and the large flat surface. The results obtained indicate that in the case of fine materials the effect of the interaction of the fluid and solid surface is slightly different ${ }^{26}$ than with large surfaces. Therefore the analogical modifications methods applied for the layer or internal hydrophobization cannot be applied because the results would be different than expected as it took place when the ethereal solutions were used.

Stearic acid vapours and powder countercurrent flow method is acceptable for the production of waterproof limestone or other volatile dusts. It seems that it is worth dealing with modifiers other than stearic acid. Work on different sorts of fine materials and water-repellent improvers of the surface will increase the present state of knowledge in the range of fine materials hydrophobization.

This work was supported by the AGH-WPiE project no. 11.11.210.125.

\section{LITERATURE CITED}

1. Rokiel, M. (2006). Poradnik. Hydroizolacje w budownictwie. Wybrane zagadnienia w praktyce. Dom Wydawniczy Medium, Warszawa.

2. Cybulski, W. \& Tarnowski, J. (1952). Niebezpieczeństwo wybuchu pyłu węglowego i sposoby jego zwalczania. PWT, Katowice.
3. Polska Norma. (1994). Pył kamienny przeciwwybuchowy. PN-G-11020.

4. Nowakowski, N. \& Ahmad, M.S. (1993). Przyczynek do zagadnienia uodparniania tworzyw gipsowych na działanie wody. Cement - Wapno - Gips, 5, 159 - 163.

5. Domasłowski, W., Kęsy-Lewandowska, M. \& Łukaszewicz, J.W. (1998). Badania nad konserwacją murów. Uniw. M. Kopernika, Toruń.

6. Czarnecki, L., Broniewski, T. \& Henning O. (1996). Chemia w budownictwie. Arkady, Warszawa.

7. Ostrowski, C. (1983). Metody uodparniania tworzyw gipsowych na działanie wody i ich ocena. Cement - Wapno - Gips, 2, 46 - 48.

8. Chyliński, W. \& Sulewski, Z. (1977). Ocena przydatności rozcieńczalnych w wodzie środków silikonowych do hydrofobizacji płyt gipsowych i betonowych. Zesp. Rzesz., SITPChem, Warszawa.

9. Mazur, S. \& Zacharowa, M. (1961). Impregnacja powierzchniowa odlewów gipsowych i warstwy ochronne. Cement - Wapno - Gips, 1, 12 - 16.

10. Pietroń, J. (1985). Spoiwo gipsowo - anhydrytowo wapienne. Praca doktorska, AGH, Kraków.

11. Pichniarczyk, P. (2000). Hydrofobizacja lekkich poryzowanych zaczynów z gipsu syntetycznego otrzymywanego w procesie odsiarczania spalin. Praca doktorska, AGH, Kraków.

12. Ostrowski, C. (1976). Zastosowanie związków organicznych do hydrofobizacji tworzyw gipsowych, Prace Inst. Miner. Mater. Budowl., Opole.

13. Wlassak, P. (1960). Produkcja gipsu ceramicznego z surowców krajowych. Klasyfikacja dodatków przyspieszających i opóźniających proces wiązania gipsu. Cement - Wapno Gips, 6, $29-34$.

14. Pakowski, Z. \& Maciszewska, K. (2003). Ocena przydatności metod hydrofobizacji filtrów włóknistych z naniesionym aerożelem krzemionkowym. Przem. Chem., 82, (8-9), 1243 - 1249.

15. Lebecki, K. (1993). Neutralizacja osiadłego pyłu weglowego jako zabezpieczenie przed przenoszeniem wybuchu, Prace Naukowe Głów. Inst. Górn., 784.

16. Łukowski, P. (2003). Domieszki do zapraw i betonów. Polski Cement Sp. z o.o., Kraków.

17. Mizera, J. (2003). Mechanizm oddziaływania cyklicznych nawilgoceń oraz wpływ dodatków polimerów na właściwości tworzyw gipsowych. Naczelna Organizacja Techniczna, Rada w Opolu, Opole.

18. Buczek, B., Vogt, E. \& Żyła, M. (2005). Analiza możliwości hydrofobizacji pyłu wapiennego produkowanego w Kopalni Wapienia „Czatkowice”. Kraków (praca niepublikowana).

19. Buczek, B. \& Geldart, D. (1989). Wpływ drobnych cząstek na właściwości warstwy fluidalnej. Inż. Chem. i Proc., 2, 313 - 329.

20. Lasoń, M. \& Żyła, M. (1963). Aparatura do wyznaczania izoterm sorpcji i desorpcji par metoda mikrobiuretek. Chem. Anal., 8, 279 - 289.

21. Buczek, B. (1987). Oznaczanie gęstości pozornej adsorbentów i katalizatorów. Chem. Anal., 32, 969 - 974.

22. Polska, Norma. (1974). Ocena czystości powietrza. Badanie fizycznych własności pyłów. PN-74/Z-04002.

23. Thomas, M.A. (2005). Powder Density in Solid Dosage Forms, Quantachrome Instruments Corporation, from http: \|www.quantachrome.com.

24. Carr, R. (1965). Classifying Flow Properties of Solids. Chem. Eng., 72, 3, 68-72.

25. Kozłowski, B. \& Sobala, J. (1970). Walka z pyłem węglowym w kopalniach węgla kamiennego. Wyd. Ślask, Katowice.

26. Opaliński, I. (2002). Oddziaływania adhezyjne w materiałach rozdrobnionych. Wpływ stanu powierzchni i warunków przebiegu procesu na siły adhezji kapilarnej. Oficyna Wyd. Politechniki Rzeszowskiej, Rzeszów. 